\title{
Language and Ideology of Presidential and Vice-Presidential Candidates on the Republic of Indonesia 2014 Presidential and Vice-Presidential Debate Show: Critical Discourse Analysis
}

\author{
Mayasari $^{1}$, Dadang Suganda ${ }^{2}$, Nani Darmayanti ${ }^{2 *}$ \\ ${ }^{1}$ University Singaperbangsa Kawarang Jl. H.S. Ronggowaluyo Teluk Jambe Karawang 41361 \\ ${ }^{2}$ Faculty of Cultural Sciences, Universitas Padjadjaran, Bandung-Sumedang Km. 21 Jatinangor, Indonesia \\ *Corresponding Author: Mayasari, University Singaperbangsa Kawarang Jl. H.S. Ronggowaluyo Teluk \\ Jambe Karawang 41361
}

\begin{abstract}
This research is entitled "Language and Ideology of Presidential and Vice-Presidential Candidates on Presidential and Vice-Presidential Candidates Debate Show: Critical Discourse Analysis". The method used in the research is a qualitative method with Critical Discourse Analysis approach. The main theory used is the three-dimensional framework by Norman Fairclough. The research aims at (1) analyzing and formulating textual dimensions used by the Presidential and Vice-Presidential Candidates on the Presidential and Vice-Presdential Debate Show in 2014; (2) analyzing and formulating discourse dimensions (discourse practice) conveyed in the event of Presidential and Vice-Presidential Candidates Debate in 2014; (3) analyzing and formulating soci-cultural dimensions (socio-cultural practice) and events underlying the Debate of Presidential and Vice-Presidential Candidates in 2014; (4) analyzing and formulating ideologies of the Presidential and Vice-Presidential Candidates conveyed through events and the Presidential and Vice-Presidential Candidates Debate in 2014. The theories used in the research are Norman Fairclough (1992b, 1995a; 1998; 2000), Teun van Dijk (1992, 1995), Titscher (2009), Jorgensen (2007), and Richardson (2007). The results show that the two Presidential and Vice-Presidential Candidates have conveyed different ideologies during the Presidential and VicePresidential Debate on television. The Presidential Candidate number one conveys the ideologies of military, firmness, discipline etc. Meanwhile the Presidential Candidate number two conveys the ideologies of modesty, togetherness, and perseverance. The ideologies of the two Presidential and Vice-Presidential Candidates affect the voters in voting their Presidential and Vice-Presidential choices.
\end{abstract}

Keywords: language, ideology, critical discourse analysis, debate, politics, media, communication

\section{INTRODUCTION}

Language is a mean to communicate in human's life. Through language, human may express his/her idea, thought, and feeling. Nevertheless, Halliday (1987: 2) states that language actually consists of not only sentences, but also texts or discourse exchanging intents in the interpersonal context between one and another. The context in these exchanging intents relates to social value since it is strongly affected by the socio-cultural context of the society.

The development of role and definition of language has brought significant influences to linguistics. Lingusitics does not only involve structural or grammatical study but also it has developed into interdisciplinary studies with other fields such as sociolinguistics, pragmatics, discourse analysis, neurolinguistics, and psycholinguistics. These interdisciplinary studies show that language indeed plays an important role in all fields of social life.

One of the Linguistics disciplines which is an interdisciplinary study and able to uncover the role of language in ideological discourses is discourse analysis. The term of discourse analysis is a general term used in many disciplines with various definitions. Even though there is a degradation of these definitions, the point of tangency is the discourse analysis relating to the study of language/language use in social reality.

Language in a critical perspective is realized as a representation that plays a role in formulizing certain subjects, discourse themes, and strategies in the discourses. Therefore, the discourse analysis is used to uncover the power existing in every language process: what limits discourse, what 
perspectives must be used, what topics must be discussed. With such perspectives, the discourse considers that language always involves in a power relationship, namely in formulizing subjects and various representative acts existing in society. Due to using critical perspective, the third category of the discourse analysis is called as Critical Discourse Analysis/CDA. This is different from the discourse analysis in the first and second categories (Discourse Analysis).

One of the fields that also uses language related to the implementation of power in ideology as explained above is politics. The ideology plays an important role in the structuration of social acts. The efforts to systematically understand the social acts cannot be separated from the ideology phenomenon. A social group tends to show its identity or represent reason for this tendency because in general significant acts will always calculate other people's or group's reactions. The ideology functions also as a motive in personal projects. An ideology shows that a social group existed by the ideology has a reason to exist (Haryatmoko, 2014: 24).

Accordingly, it can be concluded that ideology and politics have a closed relationship. In the political level, a group of people may believe that their political group is the best and their ideology must be disseminate to influence other parties, as happened in the 2014 Republic of Indonesia Presidential election campaign . Thus, Republic of Indonesia 2014 Presidential election campaigns broadcast on all television channels in Indonesia are crucial to be studied critically

Based on the rationale explained, there are several research formulations. What are the textual dimension (textual practice), discourse dimension (discourse practice), socio-cultural dimension (socio-cultural practice), and ideologies used by the Presidential and Vice-Presidential candidates on the 2014 Presidential and Vice-Presidential Debate Show?

The main theories used in the research are the Critical Discourse Analysis, particularly the frameworks of Norman Fairclough (1992b, 1995a; 1998; 2000), Teun van Dijk (1992, 1995), Titscher (2009), Jorgensen (2007), and Richardson (2007). The method used in this research is qualitativedescriptive. According Bogman and Taylor as quoted in Moleong (1997: 3), the qualitative research method is a research procedure resulting descriptive data in the form of written or spoken words from the behaviours of observable people.

Approach of critical discourse analysis theoretical frame work by Norman Fairclough (1992b, 1995a; 1998; 2000) is known as three-dimentional discourse analysis. This analysis involves three level of analyses: (1) micro-level of textual description; (2) meso-level, of relation between discourse and text production interpretation, and; (3) macro-level, of socio-cultural analysis to explain relation between discourse and social process.

Norman Fairclough's critical discourse analysis studies events, for example language use in newspaper articles, films, videos, interviews, or political speeches.. Fairclough's discourse has comprehensive analysis level toward research object, applying multi-level methods of teks, discourse practice, and sociocultural practice. This critical discouse analysis is an integration of discourse theory emphasizing on language and discourse philosoply aspects, as stated by Foucault to extend to discourse structure/formation.

The data of the research are the debate data of the Presidential and Vice-Presidential candidates on June 15 2014, organized by and broadcast on Metro TV with the theme of Economic Development and Social Welfare. Participating in the 2014 Presidential and Vice-Presidential debate were two pairs of candidates, namely candidates' number one, Prabowo Subianto and Hatta Rajasa, and candidates' number 2, Joko Widodo and Jusuf Kala.

\section{Data Analysis}

\subsection{Textual Dimension (Textual Practice)}

In this part, textual representations on the 2014 Presidential and Vice-Presidential Debate Show are analyzed. The analysis is conducted based on the debate's themes presented on each session. In other words, textual representations conveying ideologies of each Presidential and Vice-Presidential candidates of Republic of Indonesia on each session are analyzed. The analysis' phase is conducted firstly based on the context. In this matter, various things relating to the context during the debate, starting from the moderator, location, participants, dynamics during the debate and many more, are 
described. Afterwards, textual representations of each Presidential and Vice-Presidential candidates based on the debate's themes are analyzed.

\subsubsection{Economic Development And Social Welfare Contexts Analysis}

The 2014 Presidential and Vice-Preseidential candidates' debate on the second phase used the theme: Economic Development and Social Welfare. The television channel hosting this second debate was Metro TV. It was also broadcasted on all television channels in Indonesia, both state-owned and private television channels. The debate started exactly at 8:00 p.m (Indonesian Western Time). The show began with singing "Indonesia Raya" by all participants.

Participaing in the second debate were only the Presidential candidate number one, namely Prabowo Subianto and the Presidential candidate number two, namely Joko Widodo. Prabowo wore white shirt and typical black peci, while Jokowi wore suit and tie. The debate was attended as well by hundreds of spectators who were the supporters of both parties.

The debate was hosted by Ahmad Erani Yustika, an academician of Brawijaya University. Ahmad Erani Yustika, born in Ponorogo (1973), graduated from the Department of Economics and Development Studies, Faculty of Economics Brawijaya University in 1996. After graduating, he actively published many papers on mass media (approximately 500 articles have been published on national newspaper/magazine) and scientific journals. In addition, he has presented papers in both nation and international seminars. In 2001, he graduated from graduate school (MSc) and in 2005 he completed his doctorate degree (Ph.D) at university of Göttingen (Georg-August-Universität Göttingen), Germany. Since 1997, he has worked as a lecturer at his alma mater and officiated as the Head of Master Degree of Economics, Economics Graduate School - Brawijaya University (20072009) and Vice-Dean I (Academic) August 2009-April 2010.

The format of this second debat, regulated by General Elections Commision, was divided into six segments, namely: (1) delivering vision and mission for 4.30 minutes (2) deepening vision and mission for 3 minutes, (3) questioning theme-related for 3 minutes (4) Question-Answer between the candidates for 3 minutes (5) closing Question-Answer for 3 minutes (6) Questions for 3 minutes. The questions on the debate were derived from various sources (ministry, state institutions, NGO, and Indonesian citizens). Afterwards, the General Elections Commision invited experts to discuss the theme and formulated questions on the debate. The following is the situation of the second debate held on June 152014.

\subsubsection{Prabowo Subianto - Hatta Rajasa}

A. Failure on Economic Development and Social Welfare Due to State's Leakage

On the second debate with the theme of Building Economy and Social Welfare, Prabowo Subianto focused more on the leakage occurred bringing failure on economic development and also social welfare. This can be observed from several data below shown by keywords as 33 lexicals of leak/leakage that happen repeatedly, lost of state's resources, corruption, western economic system, deficit etc.

1. ... Dari mana sumber daya untuk kita pakai untuk kita tumbuhkan kesejahteraan itu, Saudarasaudara sekalian pada tanggal 7 September setahun yang lalu ketua KPK kita menyatakan bahwa kebocoran dan kehilangan kekayaan Negara dari Republik Indonesia dalam setahun adalah 7.200 triliun, satu tahun. (2/1/008/PS)

(...from where all those resources that we use for our prosperity, ladies and gentlemen on September 7 last year, the Chief of Corruption Eradication Commision stated that the leakage and lost of the state's resources of Republic of Indonesia reached 7,200 trillion a year)

2. Dari produktivitas yang akan kita ciptakan dari penghematan kebocoran negara yang 1000 triliun tadi ini adalah strategi besar kita, jadi saudara moderator dan saudara saudara sekalian kita mengerti tantangan-tantangan yang akan kita hadapi (2/3/009/PS)

(Of the productivity that we will create from saving the state's leakage which reached 1000 trillions is our grant strategy, thus distinguished moderator and ladies and gentlemen, we understand the obstacles that we are going to face) 
3. ...kekayaan negara dan kekayaan negara kita sekarang bocor, pak Joko Widodo itu esensinya ini yang saya perjuangkan kepada seluruh elit Indonesia kekayaan kita bocor, ketua KPK pada 7 september 2013 mengatakan bocornya 7000 triliun persisnya 7200 triliun itu angka real, angka saya 1.134 triliun bocornya.... (2/4/013/PS)

(...the state's resources and our state's resources is leaking, Mr. Joko Widodo, that is the essence I put forward for to all elites of Indonesia, our resources leaked, the Chief of the Curroption Eradication Commission on September 2013 stated that the leakage reached 7,000 trillion, 7,200 trillion to be exact, this is real number, my number states the leakage reaches 1,134 trillion...)

B. Economic Development and Social Welfare through People's Economic System

In his vision and mission regarding Economic Development, the candidates of Prabowo-Hatta introduced People's Economy as their grant program. This is shown by the lexicals/phrases of people's economy, economy for people, economy and people's welfare.

4. ...iklim investasi atau kebijakan investasi kami terbuka kami mendukung investasi asing tapi tentunya tidak boleh mematikan ekonomi rakyat, harus kita perkuat koperasi harus kita perkuat usaha kecil dan menengah dan untuk itu kita harus mengalirkan dana yang lebih yang masif yang tidak tanggung-tanggung untuk memperkuat ekonomi rakyat....(2/2/003/PS)

(...our investment climate or investment policies are open to foreign investment but certainly by not killing people's economy, we must strengthen cooperatives and small and medium enterprises and for that we must distribute more massive fund without hesitation for strengthening people's economy...)

5. ...ekonomi dan kesejahteraan rakyat. Perjuangan kami Prabowo-Hatta memang ingin mewujudkan suatu ekonomi yang kuat yang berdikari yang mengamankan kekayaan negara supaya bangsa Indonesia menguasai kekayaannya dan agar kekayaan Indonesia tidak mengalir ke luar negeri, uang ini kekayaan ini akan kita pergunakan untuk kepentingan rakyat kita untuk mempercepat pembangunan untuk menaikkan penghasilan buruh tani nelayan pedagang kecil pegawai negeri PKL guru termasuk guru honorer yang penghasilannya sangat-sangat rendah juga karyawan pabrik yang tidak menentu nasibnya karena outsourcing juga mereka kaum disabilitas ini semua harus kita bantu, dari mana uang untuk membantu? Dari kekayaan negara yang harus kita amankan.... (2/6/039/PS)

(...economy and people's welfare. Our fight, Prabowo-Hatta, is indeed to realize a strong independent economy that saves the state's resources so that Indonesia rules its resources and in order for the Indonesian resources to not to flow overseas, we will fight for this money, these resources to be used for our own people, fastening development to raise the income of labors, farmers, fishermen, small sellers, civil servants, teachers, including contract teachers who receive low salary along with outsourcing labors and disabled people that we must help, where does the money come from? It comes from the state's resources that we must secure...)

C. Economic Development and Social Welfare are Our Responsibility: Ours

On the second debate, Prabowo Subianto was quite dominant in producing pronoun we (inclusive and exclusive) in each of his statements. The pronoun 'we' (exclusive) refers to Prabowo Subianto and Hatta Rajasa. Meanwhile 'we' (inclusive) refers to Prabowo Subianto, Hatta Rajasa, and all Indonesian people. This is shown in the following data.

6. ...kita membahas pembangunan ekonomi dan kesejahteraan manusia, kita mengerti tujuan kita bernegara adalah untuk mencapai kemakmuran kita bersama, masalahnya adalah bagaimana mencapai itu, banyak program indah, bagus, kita harus begini kita harus begitu kita harus membangun ini membangun itu pendidikan gratis kesehatan gratis dan sebagainya, masalahnya dari mana uangnya?.... (2/1/008/PS)

(...we are discussing building economy and human's welfare, we understand our aim in state level that is to achive our prosperity, the problem is how to achieve that, many great programs, we must do this, we must do that, we must build free education, free health program, and so on, the problem is where does the money come from?...

7. ... kami menggunakan angka 1.000 triliun yang hilang, 1.000 triliun saja sudah fantastis sudah luar biasa besarnya, di sinilah rencana kami Prabowo Subianto-Hatta Rajasa manakala kami menerima mandat dari rakyat Indonesia ini sasaran kami, kami ingin menutup kebocoran 1.000 
triliun itu, kami ingin menghemat, kami ingin memangkas, dan kami ingin mengalirkan yang 1.000 triliun bocor kita alirkan untuk membangun ekonomi kerakyatan, ekonomi untuk rakyat Indonesia bukan rakyat untuk ekonomi, kita.... (2/1/009/PS)

(...we use the number of 1,000 trillion that was lost, the 1,000 trillion is quite fantastic and great in numbers, here is our plan Prabowo Subianto-Hatta Rajasa in case we receive the mandate from Indonesian people, this is our goal, we want to fix the leakage of 1,000 trillion, we want to save, we want to cut and we want to use the leaked 1,000 trillion for building people's economy, economy for Indonesian people not people for economy, we...)

8. ...kita akan menjadi negara kuat kita akan menjadi negara terhormat karena justru kita negara yang menguasai kekayaan kita sendiri kekayaan negara Indonesia harus untuk rakyat Indonesia dan kita tidak boleh kita biarkan bocor terus atau mengalir keluar negeri, itulah tekad kami itulah keyakinan kami, kami yakin manakala kami menerima mandat kami.... (2/1/010/PS)

(..we will become a strong country we will become a respected country because we are the ones who control our own resources, the resources of Indonesia must be used for Indonesian people and we cannot let this leakage continue or flow overseas, this is our spirit, this is our belief, we are sure in case we receive our mandate..)

D. Firmness, Bravery, and Hard Work of the Leader Encourage the Success of Economic Development and Social Welfare

On the second debate, Prabowo always pointed out leadership characteristics, of which one must be brave, firm, and hard working in order to be a leader who can realize Economic Development and successful Social Welfare. This is shown through several lexicals such as hard working, brave, working hard, extraordinary discipline, etc.

9. ... kami akan menambah sawah 2 juta Hektar, kami akan menambah 2 juta hektar untuk bio etanol kami akan membangun $3.000 \mathrm{~km}$ jalan raya $4.000 \mathrm{~km}$ kereta api 8 pelabuhan kami akan membuat bank tani dan nelayan dan bank koperasi dan lembaga tabung haji, saudara-saudara dananya ada uangnya ada tinggal kemauan kita berani atau tidak kita kerja keras berani atau tidak kita pangkas kebocoran berani atau tidak kita berantas korupsi. (2/1/009/PS)

(...we will add 2 million hectares, we will add 2 million hectares for bio-ethanol, we will build $3.000 \mathrm{~km}$ of roads, $4.000 \mathrm{~km}$ of railways, 8 sea ports, we will create banks for farmers and fishermen and cooperative banks and hajj saving institutions, ladies and gentlemen the fund is there at our disposal as long as we are brave and hard-working to cut the leakage and eradicate corruption.)

10. Itu tekad Prabowo Subianto-Hatta Rajasa dan seluruh koalisi merah putih kami akan bekerja keras sekeras-kerasnya untuk melakukan itu sehingga penghasilan bangsa Indonesia akan naik sehingga kita akan menjadi negara kuat kita.... (2/1/010/PS)

(That is the determination of Prabowo Subianto-Hatta Rajasa and all red-white coalition we will work very hard to do such a thing so that the Indonesia's income will increase and we are going to be a strong nation...)

11. ... perkara sudah ada UU Desa alhamdulilah kalau nanti angkanya tidak $1 \mathrm{M}$ pemerintah kita Prabowo Subianto-Hatta Rajasa kita akan bekerja keras supaya bisa sampai 1M atau lebih itu saya katakan. (2/5/024/PS)

(...regarding the Village Constitution, thanks to God, should the number does not reach 1 billion, our government Prabowo Subianto-Hatta Rajasa will work very hard to achieve 1 billion or more I promise.)

12. Dari kekayaan negara yang harus kita amankan, apabila kita diberi mandat kita akan bekerja keras agar setiap ibu setiap pagi senyum melihat anaknya berangkat sekolah dengan.... $(2 / 6 / 039 / \mathrm{PS})$

(Of the state's resources that we must secure, should we are given the mandate, we will work very hard so that every mother in every morning will smile seeing her child go to school with...) 


\subsubsection{Joko Widodo - Jusuf Kala}

A. Independent Economic Development Started from Mental Revolution

In his vision and mission regarding the Economic Development, Joko Widodo focused more on Mental Revolution as a starting point of Indonesia's economiv development movement. This can be referred by several lexicals/phrases such as character revolution, economic development, independent economy, productivity, work ethic etc. as shown in the following data.

13. ...ekonomi yang lebih baik ekonomi Indonesia yang lebih baik, bagi saya ekonomi ditujukan sebesar-besarnya untuk kemakmuran rakyat itulah ekonomi yang berdikari, pembangunan ekonomi menurut kami ke depan yang pertama dilakukan adalah pembangunan manusianya terlebih dahulu, lewat apa? Lewat pendidikan, pendidikan yang seperti apa? Revolusi mental harus kita lakukan. $(2 / 1 / 005 / \mathrm{JW})$.

(...better economy better Indonesian economy, to me economy is used at most for people's prosperity, that is the independent economy, the economic development according to us in the future, it must prioritizes the people's development, through what? Through education, what kind of education? Mental revolution must be upheld.)

14. ...pembangunan koperasi, pembangunan UMKM, pembangunan pasar tradisional, pembangunan ekonomi pertanian dan ekonomi maritim serta industrinya dan juga pembangunan yang dimulai dari daerah pembangunan yang dimulai dari desa dan infrastruktur. Inilah yang kami maksud jalan kebaikan yang akan membuat rakyat semakin sejahtera yang akan membuat ekonomi kita kokoh dan berdaya saing tinggi sehingga ekonomi Indonesia disebut ekonomi yang berdikari.... (2/1/006/JW)

(...cooperatives development, SME development, traditional markets development, agriculture economic development, and maritime economic development along with the industries and also the development started from regional district of villages and infrastructures. This is what we mean as good ways that will make people more prosperous and our economy stronger and competitive so that the Indonesian Economy is called Independent Economy.)

15. ...pendidikan mental pembangunan sikap dan mental baru yang $20 \%$ itu pengetahuan, yang di SMP 60-40, 60 pendidikan karakter 40 pengetahuan, di SMA/SMK 20-80, 80 adalah pengetahuan dan keterampilan oleh sebab itu dengan cara inilah kita kan mendapatkan manusia manusia dengan sikap mental yang mempunya etos kerja mempunyai budaya kerja sehingga jika kita lakukan itu ke depan kita akan mempunyai manusia dengan produktivitas yang tinggi dan daya saing yang tinggi.... (2/4/017/JW).

(...character education, characteristics development and 20\% of knowledge education, 60-40 at middle school, $60 \%$ of characteristics education 40\% of knowledge, 20-80 at high school, $80 \%$ knowledge and skills therefore we will have people with characteristics who have work ethic and should this is implemented we will have people with high productivity and competitive...)

16. ...produktivitas yang tinggi daya saing yang tinggi sehingga kekayaan alam yang ada di negara kita dikelola oleh kita sendiri orang-orang Indonesia warga-warga Indonesia dan itu bisa kita lakukan kalau kita mempunyai manusia yang mempunyai pendidikan yang mempunyai produktivitas yang mempunyai daya saing baik....(2/4/018/JW)

(...high productivity, high competitiveness makes us manage our own resources by our own Indonesian people and that we can do should we possess people with better education, productivity and competitiveness...)

B. The Development of Established and Transparent System is the Key to Success Economic Development

The economic development to Joko Widodo, besides realized through mental revolution, was also realized through established and transparent system development. Building an established and transparent system may avoid various leakages that can obstruct and damage the process of economic development and social welfare.

17. ...pembangunan pasar tradisional pembangunan ruang-ruang untuk PKL saya kira saya sudah menjalani itu dan membuktikan itu, pengalaman saya membangun pasar waktu menjadi Walikota, pengalaman saya membangun pasar waktu menjadi Gubernur saya kira menjadi pengalaman 
yang sudah dibuktikan bahwa yang kecil-kecil ini harus diurus PKL, pedagang pasar karena apa pasar tradisional ....(2/2/005/JW)

(...the developments of traditional markets, spaces for street vendors I think I have done those thing and have proved them, my experience in developing markets when I was a mayor, my experience building markets when I was a Governor I think it becomes proofs that something small must be managed by the street vendors, the market vendors because what traditional markets...)

18. ...efisiensi di APBN asal penyimpangan dan kebocoran di APBN ini bisa dikurangi terus dengan cara apa? Membangun sistem seperti yang sudah saya sampaikan pakai E-budgeting Eaudit pakai E-progresif....(2/2/006/JW)

(...efficiency in state budget against the deviation and leakage in the state budget can be reduced with what? Building a system like I have done it through E-budgeting E-audit using E-progressive...)

19. ...masalah kemiskinan memang harus kita berani memberikan program khusus bagi masyarakat yang kurang beruntung tapi bukan hanya disiapkan anggarannya saja yang paling penting menurut saya adalah sistemnya yang dibangun, sistemnya dulu yang dibangun oleh sebab itu kenapa waktu menjadi Walikota dan menjadi Gubernur kami selalu berkonsentrasi selalu di bidang pendidikan dan kesehatan karena apa? Di bawah keluhannya selalu itu, oleh sebab itu ke depan tadi sudah saya sampaikan akan kita berikan yang namanya kartu Indonesia Indonesia pintar seperti ini untuk masyarakat anak-anak dari masyarakat yang kurang mampu.... (2/3/002/JW)

(...we must be firm in providing particular programs for fight agaist poverty to those who are less fortunate but not only preparing the budget, the most important thing I believe is to build a system, a system must be built first, that is why when I was a mayor and governor we always concentrate on education and health why? The complains in the roots are always about those things therefore, in the future, as I explained, we will give what we call as Smart Indonesia Card like this for children from poor family...)

20. ...investasi harus harus didorong ke daerah-daerah ke provinsi-provinsi yang tingkat kemiskinannya besar dengan cara itu yang ada di daerah tidak menuju kota dengan cara itu yang miskin.... (2/3/003/JW).

(...investment must be encouraged to regions to provinces with high poverty levels, by doing this they will stay and will not go to the cities, by this way the poor ones.)

C. Economic Development and Social Welfare are Our Responsibility: Mine and Ours

On this second debate, Prabowo Subianto was dominant in producing pronoun 'we' (exclusive and inclusive) in each of his statement. It is different from Joko Widodo who was dominant in using pronouns ' $\mathbf{I}$ ' and 'We' in referring those who are responsible for Economic Development and Social Welfare. 'I' refer to Jokowi and his success in developing Economy and Social Welfare when he was a mayor of Solo and Governor of Jakarta. Meanwhile, the pronoun 'We' refers to Jokowi, Jusuf Kalla and all Indonesian people. Pay attention to several data below.

21. ...kita semua hom swastiastu, yang saya hormati bapak Prabowo Subianto, yang saya hormati moderator ibu bapak sekalian saudara-saudara sebangsa dan setanah air, saya berdiri di sini karena saya saat bertemu ibu Lili tukang cuci dari Manado Sulawesi Utara, saya bertemu pak Abdulah nelayan dari Sumatra Utara, serta saat saya ke Banyumas saya bertemu ibu Satinah buruh tani yang setiap hari bekerja di sawah, dan saya juga bertemu pak Azad seorang guru di Jawa Barat, dan jutaan orang yang ada di negara ini yang menitipkan pesan menitipkan harapan-harapan pada kami untuk membangun sebuah ekonomi yang lebih baik ekonomi Indonesia yang lebih baik, bagi saya ekonomi ditujukan sebesar-besarnya untuk kemakmuran rakyat itulah ekonomi yang berdikari, pembangunan ekonomi menurut kami....(2/1/005/JW)

(...we all hom swastiasu, distinguished Mr. Prabowo Subianto, moderator ladies and gentlemen, brothers and sisters, I stand here because when I met Mrs. Lili the washer from Manado North Sulawesi, I met Mr. Abdullah the fishermen from North Sumatra, and when I went to Banyumas, I met Mrs. Satinah a farmer who worked everyday in the rice field and I also met Mr. Azad a teacher from West Java and millions of people in this country have sent their messages and hopes to us to build a better economy, a better Indonesian economy, to me economy is greatly used for the prosperity of people, that is the independent economy, economic developmet according to us...) 
22. ...kita sudah meningkat kita kan mempunyai sebuah daya saing karena produkivitas akan memunculkan sebuah daya saing, yang kedua yaitu masalah pertumbuhan ekonomi yang diikuti dengan pemerataan, percuma pertumbuhan ekonomi baik kalau pemerataan itu tidak ada oleh sebab itu pemerataan akan menjadi sebuah perhatian bagi kami berdua Jokowi dan JK. Pembangunan seperti apa yang ingin kita lakukan? Pembangunan koperasi, pembangunan UMKM, pembangunan pasar tradisional, pembangunan ekonomi pertanian dan ekonomi maritim serta industrinya dan juga pembangunan yang dimulai dari daerah pembangunan yang dimulai dari desa dan infrastruktur. Inilah yang kami.... (2/1/006/JW)

(...we have improved we are competitive because productivity results to competitiveness, the second is the problem of economic growth followed by equalization, it is such a waste for better economic growth without equalization, therefore equalization will become a huge concern to us, Jokowi and JK. What kind of development that we want? The developments of cooperative, SME, traditional markets, agricultular economy and maritime economy along with its industries and the development started from local regions, the development from villages and infrastructures. This is us...)

D. Listening Directly to People's Voices and Success in Previous Leadership Results in Success of Economic Development and Social Welfare

In this matter, Jokowi also mentioned which characteristics that must be possessed by a leader. It was different from what Prabowo explained about leadership that pointed out firmness and fast leader. In such a matter, Jokowi focused more on the fact that leadership must involve directly to the fields, listening to people's voices (blusukan) and the success of his leadership in Solo and Jakarta was a guarantee that his leadership has been proven. Look at several examples below.

23. ... saya saat bertemu ibu Lili tukang cuci dari Manado Sulawesi Utara, saya bertemu pak Abdulah nelayan dari Sumatra Utara, serta saat saya ke Banyumas saya bertemu ibu Satinah buruh tani yang setiap hari bekerja di sawah, dan saya juga bertemu pak Azad seorang guru di Jawa Barat, dan jutaan orang yang ada di negara ini yang menitipkan pesan menitipkan harapan-harapan pada kami.... (2/1/005/JW)

(...when I met Mrs. Lili the washer from Manado North Sulawesi, I met Mr. Abdullah te fishermen from North Sumatra, and when I went to Banyumas, I met Mrs. Satinah a farmer who worked everyday in the rice field and I also met Mr. Azad a teacher from West Java and millions of people in this country have sent their messages and hopes to us..)

24. ... buktikan waktu menjadi gubernur di Jakarta....(2/3/003/JW)

(...proven when becoming the Governor of Jakarta...)

Table1: Formulations of Micro Analysis of the Presidential and Vice-Presidential Candidates on the Second Debate: Economic Development and Social Welfare

\begin{tabular}{|c|c|c|c|c|}
\hline No & \multicolumn{2}{|c|}{$\begin{array}{c}\text { Micro Analysis (Textual) Prabowo-Hatta } \\
\text { Rajasa }\end{array}$} & \multicolumn{2}{|c|}{$\begin{array}{l}\text { Micro Analysis (Textual) Joko Widodo - Jusuf } \\
\text { Kalla }\end{array}$} \\
\hline 1. & $\begin{array}{l}\text { Failure on Economic } \\
\text { Development and Social } \\
\text { Welfare Due to State's } \\
\text { Leakage }\end{array}$ & $\begin{array}{l}\text { leaked/leakage, lost } \\
\text { of state's resources } \\
\text { corr uption, western } \\
\text { econo mic system, } \\
\text { deficit }\end{array}$ & $\begin{array}{lr}\text { Independent } & \text { Economic } \\
\text { Development } & \text { Started } \\
\text { from Mental Revolution }\end{array}$ & $\begin{array}{l}\text { mental revolution, } \\
\text { economic development, } \\
\text { independent } \begin{array}{l}\text { economy, } \\
\text { productivity, work ethic }\end{array}\end{array}$ \\
\hline 2. & $\begin{array}{l}\text { Economic Development } \\
\text { and Social Welfare } \\
\text { through } \\
\text { Economic System }\end{array}$ & $\begin{array}{l}\text { people's economy, } \\
\text { economy for for peo } \\
\text { ple, people's } \\
\text { economy, people's } \\
\text { economy and welfare }\end{array}$ & $\begin{array}{l}\text { The Development of } \\
\text { Established and Trans } \\
\text { parent System is the Key } \\
\text { to Success Economic } \\
\text { Development }\end{array}$ & $\begin{array}{l}\text { E-budgeting E-audit using } \\
\text { E-progressive Building Per } \\
\text { mit for example can be onli } \\
\text { ne as well as business lice } \\
\text { nse, long-term develo ment }\end{array}$ \\
\hline 3. & $\begin{array}{l}\text { Economic Developme nt } \\
\text { and Social Welfare are } \\
\text { Our Responsibility: Ours }\end{array}$ & $\begin{array}{l}\text { I } \\
\text { We (exclusive) } \\
\text { We (inclusive) }\end{array}$ & $\begin{array}{l}\text { EconomicDevelopment } \\
\text { and Social Welfare are } \\
\text { Our Responsibility: Mine } \\
\text { and Ours }\end{array}$ & $\begin{array}{l}\text { I } \\
\text { We (exclusive) } \\
\text { We (inclusive) }\end{array}$ \\
\hline 4. & $\begin{array}{l}\text { Firmness, Bravery, and } \\
\text { Hard Work of the Leader } \\
\text { Encourage the Success of } \\
\text { Economic Development } \\
\text { and Soc ial Welfare }\end{array}$ & $\begin{array}{l}\text { firm } \\
\text { hard-working } \\
\text { brave }\end{array}$ & $\begin{array}{l}\text { Previous Success of } \\
\text { Leadership is A guara } \\
\text { ntee of the success of } \\
\text { Economic Development } \\
\text { and Social Welfa re }\end{array}$ & $\begin{array}{l}\text { Stated in the strategy of } \\
\text { adding subordinate clause }\end{array}$ \\
\hline
\end{tabular}




\section{CONCLUSION}

This research shows that the two Presidential and Vice-Presidential candidates have delivered different ideologies during the debate on television. The Presidential candidate number one conveys the ideologies of military, firmness, discipline, etc. Meanwhile the Presidential candidate number two conveys the ideologies of modesty, togetherness and perseverance. The ideologies of the two Presidential and Vice-Presidential candidates affect the voters in voting their Presidential and VicePresidential choices.

These two different ideologies from two candidates of President and Vice-President in 2014 Republic of Indonesia Presidential and Vice-Presidential Debate were connected from the personal background of both president and vice president candidates. President Candidate number 1 Prabowo Subianto is a former General in Indonesian Armed Forces with military background and strict, discipline, and brave capabilities. Many of his statements throughout the debate were delivered strictly based on his background as Kopassus (Special Forces Command) Chief. Meanwhile Hatta Rajasa as Vice President candidate had good management, political, and technical background.. As former Ministry of Coordinator for Economy, former Minister of Transportation, and Former Minister of Research and Technology, Hatta Rajasa statements were always based on experience and scientific research, supported by field data and facts.

Candidate of President number 2, Joko Widodo was a businessman and politician who was the mayor of Solo. He is known by his blusukan method and being close with the people, modest, and quick on his feet. This became part of his qualities in his statements in the debate.. Meanwhile Jusuf Kalla who also has business and political background, was the Vice President in the 2004-2009 period. His nimble, quick, and straightforward characters were always apparent in his statements during the debate. Aside from the profiles of both president and vice president candidates, the ideology background of the parties of these two candidates are influenced heavily both text representation by these two candidates.

\section{REFERENCES}

[1] Agger, Ben. 1999. Teori Sosial Kritis. Yogyakarta: Kreasi Wacana.

[2] Alwasilah, A. Chaedar. 2002. Pokoknya Kualitatif: Dasar-dasar Merancang dan Melakukan Penelitian Kualitatif. Bandung : Pustaka Jaya.

[3] Beard, A. 2000. The Language of Politics. London: Routledge.

[4] Brown, Gillian dan George Yule. 1996. Analisis Wacana. Jakarta: PT Gramedia.

[5] Djajasudarma, T. Fatimah. 2006. Metode Linguistik: Ancangan Metode Penelitian dan Kajian. Bandung : PT Eresco.

[6] Dosi, Eduardus. 2012. Media Massa dalam Jaring Kekuasaan. Yogyakarta: Ledoardo.

[7] Eriyanto. 2006. Analisis Wacana: Pengantar Analisis Teks Media. Yogyakarta: LKIS.

[8] Fairclough, Norman. 1989. Language and Power. London: Longman.

[9] Fairclough, Norman. 1992a. Discourse and Sosial Change. Cambridge: Polity Press.

[10] Fairclough, Norman. 1992b. Discourse and Text: Linguistic and Intertextual Analysis. Cambridge: Polity Press.

[11] Fairclough, Norman. 1995a. Media Discourse. London: Edward Arnold.

[12] Fairclough, Norman. 1995b. Critical Discourse Analysis: The Critical Study of Language. London: Longman.

[13] Fairclough, Norman. 1998. Political Discourse in The Media: An Analytical Framework dalam Allan Bell and Peter Garret (ed.). Approaches to Media, hlm 142 - 162. Massachusetts: Blackwell Publisher Inc.

[14] Fairclough, Norman. 2000. Critical Analysis of Media Discourse. Dalam Paul Marris and Sue Thornham (ed.). Media Studies a Reader. Hlm. 308 -328. Washington New York University Press.

[15] Franz Magnis-Suseno, Filsafat Sebagai Ilmu Kritis, Yogyakarta: Kanisius, 1992,

[16] FX. Mudji Sutrisno dan F. Budi Hardiman (ed.), Para Filsuf Penentu Gerak Zaman, Yogyakarta: Kanisius, 1992,

[17] Gee, James Paul. 1999. A Introduction to Discourse Analysis, Theory and Method. London: Routledge.

[18] Halliday, M. A. K. 1978. Language as Sosial Semiotic. London: Edward Arnold. 
[19] Haryatmoko, 2014. Etika Politik dan Kekuasaan. PT: Gramedia: Jakarta.

[20] Hikam. 1996. "Bahasa dan Politik" dalam Latif Y dan Ibrahin (ed). Bahasa dan Kekuasaan: Politik Wacana di Panggung Orde Baru. Bandung: Penerbit Mizan.

[21] Hodge, R. dan G. Kress. 1979. Language as Ideology. London. Routledge.

[22] Idris Aman. 2006. Bahasa dan Kepemimpinan Analisis Wacana Mahathir Mohammad. Bangi: Penerbit Universiti Kebangsaan Malaysia.

[23] Jorgensen, Marianne W. 2007. Analisis Wacana: Teori dan Metode. dalam Abdul Syukur Ibrahim (Ed.). Yogyakarta: Pustaka Pelajar.

[24] Jurgen Habermas. 1990. Ilmu Dan Teknologi Sebagai Ideologi, Jakarta: LP3ES,

[25] Lubis, Akhyar Yusuf. 2015. Pemikiran Kritis Kontemporer. Depok: Radjagrafindo.

[26] Moleong, Lexy. 1991. Metodologi Penelitian Kualitatif. Bandung: PT Rosda Karya.

[27] Phillips, L. dan Marianne W. Joergensen. 2002. Discourse Analysis as Theory and Method. London: Sage Publication.

[28] Rahmat, J. 1996. "Komuikasi dan Perubahan Politik di Indonesia" dalam Latif Y dan Ibrahin (ed). Bahasa dan Kekuasaan: Politik Wacana di Panggung Orde Baru. Bandung: Penerbit Mizan.

[29] Richardson. 2007. Analysing Newspaper: An Approach from Critical Discourse Analysis. England: Paldrave Macmillan.

[30] Santoso, Anang. 2012. Studi Bahasa Kritis. Bandung: Penerbit Mandar Maju.

[31] Satoso, Anang 2003: Bahasa Politik Pasca Orde Bsru.Jakarta: Wedatama Widya Sastra.

[32] Shriffin, Deborah. 2007. Ancangan Kajian Wacana. Terjemahan Abdul Syukur Ibrahim. Yogyakarta: Pustaka Pelajar.

[33] Sudaryanto. 1993. Metode dan Teknik Penelitian Linguistik. Yogyakarta: Duta Wacana.

[34] Thomas McCartny. 1990. Communication and the Evolution of Society, London: Heinemann.

[35] Thompson, Jhon B. 2015 Kritik Ideologi Global. IRCiSoD. Yogyakarta.

[36] Titscher, Stefan. 2009. Metode Analisis Teks dan Wacana dalam Abdul Syukur Ibrahim (Editor). Yogyakarta: Pustaka Pelajar.

[37] Wijana, I Dewa Putu dan Muhamad Rohmadi. 2009. Analisis Wacana Pragmatik: Kajian Teori dan Analisis. Surakarta: Yuma Pustaka.

[38] Wodak, R. 1996. Disorders of Discourse. London: Longman.

\section{AUTHOR'S BIOGRAPHY}

Dr. Mayasari is a Lecturer at Faculty of Social dan Political Sciences University of Singaperbangsa Karawang. Her research interests are critical discourse analysis, media, politics, and sociolinguistics.

Prof. Dr. Dadang Suganda is Professor of Linguistics in Faculty of Cultural Sciences Universitas Padjadjaran. His expertises are critical discourse analysis, sociolinguistics, and pragmatics.

Nani Darmayanti, Ph.D. is lecturer of linguistics in Faculty of Cultural Sciences Universitas Padjadjaran. Her research interests are critical discourse analysis, sociolinguistics, and pragmatics.

Citation: Mayasari, Dadang Suganda, Nani Darmayanti. "Language and Ideology of Presidential and VicePresidential Candidates on the Republic of Indonesia 2014 Presidential and Vice-Presidential Debate Show: Critical Discourse Analysis". International Journal on Studies in English Language and Literature (IJSELL), vol 6, no. 7, 2018, pp. 16-25. doi:http://dx.doi.org/10.20431/2347-3134.0607003.

Copyright: (C) 2018 Authors. This is an open-access article distributed under the terms of the Creative Commons Attribution License, which permits unrestricted use, distribution, and reproduction in any medium, provided the original author and source are credited. 